\title{
Cluster Analysis of mRNA Expression Levels Identifies Multiple Sequential Patterns Following Focal Cerebral Ischemia
}

\author{
mRNA Ekspresyon Düzeylerinin Kümeleme Analizi Fokal Serebral \\ İsemi Sonrasında Çoklu Dizisel Paternler Tanımlamaktadır
}

Takanobu KAIDO ${ }^{1}$, Oliver KEMPSKI ${ }^{1}$, Axel HEIMANN ${ }^{1}$, Cara HEERS ${ }^{2}$, Daniela BARTSCH ${ }^{2}$

1 Johannes Gutenberg University Mainz, Institute for Neurosurgical Pathophysiology, Mainz, Germany

2 Janssen Research Foundation, Neuss, Germany

Correspondence address: Takanobu KAIDO / E-mail: kaido@ncnp.go.jp

\begin{abstract}
AIM: The purpose of this study is to detect gene expression patterns following focal cerebral ischemia.

MATERIAL and METHODS: 25 male Wistar rats were divided into control $(n=8)$ and ischemic $(n=17)$ groups. In the ischemic group, slowly progressing focal ischemia was simulated by two-vein occlusion with spreading depression (SD) a cortical microinjection of KCl induced. Ischemic tissue was removed at 2,8,24, or $72 \mathrm{~h}$ postischemia. Using semiquantitative reverse transcription polymerase chain reaction, we investigated mRNA expression levels of 13 representative genes related to cerebral ischemia. Cluster analysis of the gene expression levels was done.

RESULTS: In the ischemic group, the expression levels of c-fos, cyclin D1, and COX-2 were significantly higher at $2 \mathrm{~h}$ postischemia, and those of bcl-2, bcl-xL, and $\mathrm{HO}-1$ at $72 \mathrm{~h}$. Based on the cluster analysis, we statistically divided examined genes into three groups: group A, early expression (COX-2, c-fos, and bcl-2); group B, s expression (c-jun, SOD-1, bad, p53, SOD-2, bcl-xL, and bax); and group C, late expression (cyclin D1, c-myc, and HO-1).

CONCLUSION: We statistically classified the genes into three groups after focal ischemia. The genes of the early- and late-expression groups can be possible therapeutic targets for the treatment of cerebral ischemia.
\end{abstract}

KEYWORDS: mRNA, Focal cerebral ischemia, Venous occlusion, Spreading depression, Cluster analysis

öz

AMAÇ: Bu çalışmanın amacı, fokal serebral iskemi sonrasında gen ekspresyonu paternlerini çalışmaktı.

YÖNTEM ve GEREÇLER: 25 erkek Wistar sıçanı kontrol $(n=8)$ ve iskemik $(n=17)$ gruplarına bölündü. İskemik grupta yayılan depresyon (SD) ve kortikal $\mathrm{KCl}$ mikroenjeksiyonu yoluyla iki damar oklüzyonu simüle edildi. İskemik doku, iskemiden 2, 8, 24 veya 72 saat sonra çıkarıldı. Semikantitatif revers transkripsiyon polimeraz zincir reaksiyonu kullanarak serebral iskemiyle ilişkili 13 temsili genin mRNA ekspresyon düzeyini inceledik. Gen ekspresyonu düzeylerinin kümeleme analizi yapıldı.

BULGULAR: İskemik grupta c-fos, siklin D1 ve COX-2 ekspresyon düzeyleri iskemiden sonra 2 saatte önemli ölçüde yüksekti ve bcl-2, bcl-xL ve HO-1 ekspresyon düzeyleri 72 saat önemli ölçüde yüksekti. Kümeleme analizi temelinde incelenen genleri üç gruba ayırdık: Grup $A$ erken ekspresyon (COX-2, c-fos, ve bcl-2); Grup B, stabil ekspresyon (c-jun, SOD-1, bad, p53, SOD-2, bcl-xL, ve bax); ve Grup C, geç ekspresyon (cyclin D1, c-myc, ve HO-1).

SONUÇ: Genleri fokal iskemiden sonra istatistiksel olarak üç grupta sınıflandırdık. Erken ve geç ekspresyon gruplarının genleri serebral iskemi tedavisinde olası terapötik hedefler olabilir.

ANAHTAR SÖZCÜKLER: mRNA, Fokal serebral iskemi, Venöz oklüzyon, Yayılan depresyon, Kümeleme analizi

\section{INTRODUCTION}

With regards to the duration of open time window to treat acute brain ischemia, several methodologies are available for its treatment, including thrombolysis, hemodilution, and vascular reconstructive surgery, in addition to treating vital conditions. These therapies help to maintain or increase cerebral blood flow (CBF), but do not trigger intracellular genetic cascades. However, once CBF falls below the threshold, several genetic cascades are believed to get activated in neurons, resulting in necrosis or apoptosis. Therefore, because the current treatments for acute brain ischemia are limited to blocking the source of the stream, the therapeutic time window is still very small. 
To increase the therapeutic window time, the downstream cascades must be stopped in order to prevent progression to necrotic or apoptotic processes. Analysis of gene expression levels after ischemia can provide valuable information regarding this issue. There are several molecular mechanisms associated with ischemic neuronal death, including spreading depression (SD), calcium influx, apoptosis, inflammation, oxidative stress, cell-cycle disorders, the expression of immediate early genes, proto-oncogenes, and heat shock proteins, etc. Researchers should be aware of the time at which genes are expressed after the onset of cerebral ischemia, since they may help them directly target those genes using therapeutic agents.

The slower the currency of the stream is, the better scanning of its contents such as genetic changes is. We previously reported an experimental model of focal cerebral ischemia induced by $\mathrm{KCl}$, resulting in venous occlusion with $\mathrm{SD}$. This model demonstrates slowly progressive and reproducible infarction (7-8). We believe that this model is suitable for gene expression analysis following focal cerebral ischemia. However, because the number of induced SDs in this model can cause variations of the infarction volume (7-8), SD should only be induced when attempting to reproduce homogenous infarcts.

To detect the patterns of gene expression following focal cerebral ischemia, we performed the two-vein occlusion method on rats and analyzed the mRNA expression levels of 13 representative genes, including the following: c-fos, c-jun, p53, c-myc, bcl-2, bcl-xL, bax, bad, superoxide dismutase (SOD)-1 and -2 , cyclin D1, heme oxygenase-1 (HO-1), and cyclooxygenase (COX)-2.

\section{MATERIAL and METHODS}

This study was conducted after obtaining a consent from the German animal protection legislation and has been reviewed by the regional ethics committee (Bezirksregierung Rheinhessen-Pfalz).

\section{Animal Preparation}

The experiments were conducted on 25 male Wistar rats (mean body weight: 342 g; range: 280-400 g; Charles River, Germany). The rats were housed in individual cages and were allowed free access to food and water before and after surgery. They were anesthetized using ether and an intraperitoneal injection of $0.5 \mathrm{mg}$ atropine. Anesthesia was maintained using chloral hydrate (12 mg/100 g body weight), which was administered every one hour using a peritoneal catheter. The trachea was intubated in each animal using a silicon tube ( $2.5 \mathrm{~mm}$ o.d.), and the animals were mechanically ventilated with $30 \%$ oxygen using a rodent ventilator (Model 683; Harvard Apparatus, South Natick, MA, USA) under the control of end-expiratory $\mathrm{PCO}_{2}$ monitor (Artema MM206C; Heyer, Sweden). Rectal body temperature was maintained close to $37.0^{\circ} \mathrm{C}$ throughout the experiment using a feedbackcontrolled heating pad (Harvard Apparatus). Polyethylene catheters $(0.96 \mathrm{~mm}$ o.d., Portex) were inserted into the right femoral artery and vein. The arterial line allowed continuous monitoring of the mean arterial blood pressure (MABP) and arterial blood gas levels, and the venous line allowed the administration of additional fluids and drugs. $\mathrm{PaO}_{2^{\prime}}, \mathrm{PaCO}_{2^{\prime}}$ arterial $\mathrm{pH}$, and electrolytes were measured using a blood gas and electrolyte analyzer (ABL System 615; Radiometer, Copenhagen, Denmark). Blood pressure was continuously recorded using a pressure transducer (Datascope 870 Monitor \& Pressure Display Module; Datascope Corp., Paramus, NJ, USA). All the rats were placed in a stereotaxic frame before handling (Stoelting, Wood Dale, IL, USA). After making a $2.0-\mathrm{cm}$ midline incision in the skin, a window was made to access the right frontoparietal region of the brain surface using a high-speed drill and an operating microscope (OPMicroscope; Zeiss, Wetslar, Germany). During craniectomy, the drill tip was continuously cooled using physiologic saline to avoid thermal injury to the cortex.

\section{Cortical Vein Occlusion via Photochemical Thrombosis}

Occlusion of the two adjacent cortical veins was induced using rose bengal dye (Sigma, St. Louis, MO, USA) under fiberoptic illumination by a 50-W mercury lamp (6500-7500 Ix, $540 \mathrm{~nm}$ ) connected via a 100- $\mu \mathrm{m}$ fiber. Only animals with similar venous anatomies (i.e., two prominent adjacent veins connected to the superior sagittal sinus) were used. The diameter of the occluded veins was approximately $100 \mu \mathrm{m}$. Rose bengal dye (50 mg/kg body weight) was slowly injected to avoid affecting the systemic arterial pressure, and care was taken to avoid illumination of tissues and other vessels near the target vein. The vein was illuminated for $10 \mathrm{~min}$ using a micromanipulator-assisted light guide. To occlude the second vein, half of the initial rose bengal dye was intravenously injected before the new target was illuminated. A photograph of the brain surface and a schematic drawing of the experimental set-up are shown in Figure 1A, B.

\section{Impedance Measurement}

Impedance electrodes were prepared using two stainless steel wires $(0.5 \mathrm{~mm})$ covered with polyvinyl chloride for electrical insulation (except for the $0.3-\mathrm{mm}$ sharp-pointed tip). The electrodes were implanted into the cortex $(0.4-0.5 \mathrm{~mm}$ deep and $2.0 \mathrm{~mm}$ apart) (Figure 1). Impedance was measured at $1 \mathrm{kHz}$ (10 mV, bias-free) throughout the experiment using a precision LCR monitor (4282A; Hewlett-Packard, USA).

\section{Induction of Cortical SD}

$\mathrm{KCl}$ was directly administrated to the cerebral cortex of each rat in the ischemic group. The $\mathrm{KCl}$ injector, a glass micropipette filled with $150 \mathrm{mmol} / \mathrm{L} \mathrm{KCl}$ solution, was inserted into the lateral parietal cortex. The injector was connected to a microinjection pump (CMA/100; Carnegie Medicine, Stockholm, Sweden) (Figure 1A, B).

After establishing stable impedance values, impedance was measured for $25 \mathrm{~min}$. The veins in the rats of the ischemic group were occluded during this time period. Thereafter, the clock was set to $0 \mathrm{~min}$. The rats received 10 injections of 

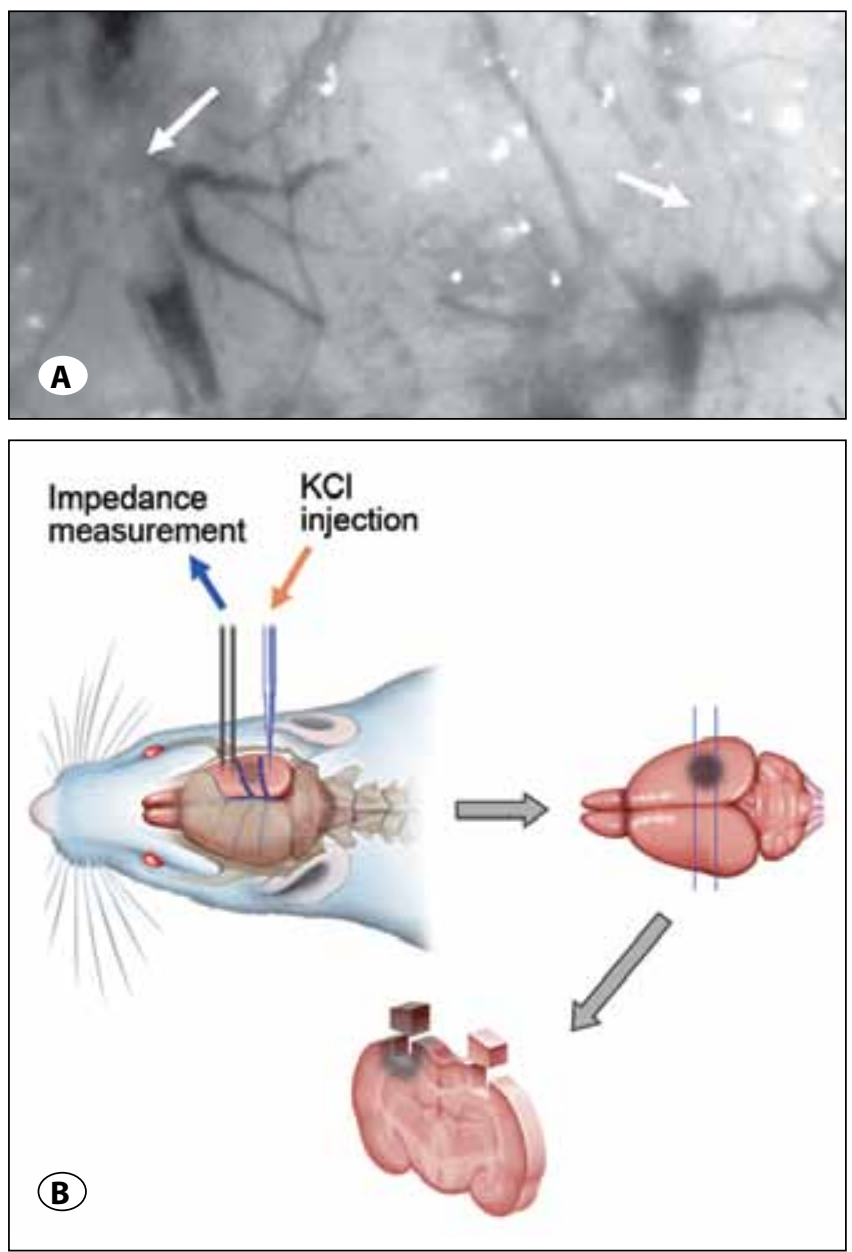

Figure 1: A) Photograph and B) schematic drawing of the experimental set-up showing the brain surface of a rat during the two-vein occlusion procedure, during which SD was induced and impedance was measured. (A) Arrows indicate the two cortical veins after occlusion. (B) Impedance electrodes $(0.5 \mathrm{~mm}$ o.d.) were implanted into the cortex $(0.4-0.5 \mathrm{~mm}$ deep and 2.0 $\mathrm{mm}$ apart). The $\mathrm{KCl}$ injector, a glass micropipette filled with 150 $\mathrm{mmol} / \mathrm{L} \mathrm{KCl}$ solution, is connected to a microinjection pump and inserted into the lateral parietal cortex. Three-mm thick coronal sections were obtained from the parietal regions. A 3-mm cubic piece of the cerebral cortex at the level of the occluded veins was separated from the coronal sections of each hemisphere for RTPCR analysis.

$\mathrm{KCl}$ solution ( $2.0 \mu \mathrm{l}$; delivered at a rate of $10 \mu \mathrm{L} / \mathrm{min}$ ) into the parietal cortex at 7, 14, 21, 28, 35, 42, 49, 56, 63, and $70 \mathrm{~min}$.

\section{Brain Tissue Removal}

After the acute experiment, the incisions were closed using silk sutures. The rats were returned to their individual cages and allowed free access to water and food, following which they were decapitated under anesthesia with chloral hydrate (at $2 \mathrm{~h}[\mathrm{n}=4]$ and $24 \mathrm{~h}$ [n=4] post-surgery in the control group, and at $2[n=5], 8[n=4], 24[n=4]$, and $72 \mathrm{~h}[\mathrm{n}=$ 4] post-surgery in the ischemic group), and their brains were immediately removed.
Three-mm thick coronal sections were obtained from the parietal regions. A 3-mm cubic piece of the cerebral cortex from the region between the occluded veins was separated from the coronal section of each hemisphere (Figure 1A,B).

The ipsi- and contralateral samples were frozen using liquid nitrogen. This was performed within 5 min after decapitation. Tissues were stored at $-70^{\circ} \mathrm{C}$ until reverse transcriptase polymerase chain reaction (RT-PCR) analysis was performed.

\section{Semi-quantitative RT-PCR}

To analyze mRNA expression levels, the total cellular RNA was extracted from the cortical tissues using the RNeasy Mini Kit (Qiagen, Hilden, Germany) according to the manufacturer's instructions. After homogenizing the tissues $(20-50 \mathrm{mg}$ ) in a lysis buffer, [Remark 1] 70\% ethanol was added, and the samples were placed in RNeasy spin columns and centrifuged $(15,000 \mathrm{rpm}$ for $1 \mathrm{~min})$. RNA was then washed with buffer RW1 and incubated with RNase-free DNase I (Qiagen) at room temperature for $15 \mathrm{~min}$. After another wash with RW1, RNA was washed twice with buffer RPE and eluted in RNase-free $\mathrm{H}_{2} \mathrm{O}$. The yield and integrity of each RNA sample was determined by spectrophotometric measurement at A260 and agarose gel electrophoresis, respectively. After destroying any secondary structures (at $70^{\circ} \mathrm{C}$ for $10 \mathrm{~min}$ ), RNA was reverse-transcribed in a $20-\mu \mathrm{L}$ reaction mixture (at $42^{\circ} \mathrm{C}$ for $1 \mathrm{~h}$ ) using oligo (dT) primers and the Reverse Transcription System (Promega, USA). The reaction was terminated by heat treatment $\left(95^{\circ} \mathrm{C}\right.$ for $\left.5 \mathrm{~min}\right)$. Three cDNA dilutions were then amplified by PCR using Taq DNA polymerase (Gibco BRL). After the first denaturation step $\left(95^{\circ} \mathrm{C}\right.$ for $\left.2 \mathrm{~min}\right), \mathrm{PCR}$ amplification was performed for $21-33$ cycles $\left(95^{\circ} \mathrm{C}\right.$ for $30 \mathrm{~s}, 58-61^{\circ} \mathrm{C}$ for 30 $\mathrm{s}$, and $72^{\circ} \mathrm{C}$ for $\left.1 \mathrm{~min}\right)$, followed by a final extension step $\left(72^{\circ} \mathrm{C}\right.$ for $5 \mathrm{~min}$ ). The primer sequences and annealing temperatures of the target genes are shown in Table I.

The amplified cDNA products were separated by electrophoresis on a 1.5\% agarose gel containing SYBR Gold (1: 10,000; Molecular Probes, USA). The intensities of the PCR products were quantified using an imaging program (ImageQuant, Molecular Dynamics, USA). The intensities of the targeted PCR products were normalized to those of the respective PCR products of the housekeeping gene, glyceraldehyde-3-phosphate dehydrogenase.

To determine how mRNA expression in the treated brain hemisphere is regulated compared to the contralateral side, ratios (ipsilateral/contralateral) of the normalized intensities were calculated.

\section{Statistical Analysis}

Data were expressed as the means \pm standard deviations. Differences were statistically evaluated using the t-test for two-group comparisons or analysis of variance (ANOVA) for multi-group comparisons. All analyses were performed using statistical software (SigmaPlot 11.0; Systat Software, Chicago, IL, USA). Results were considered statistically significant with an error probability of $p<0.05$. Cluster analysis was performed 
using the program Cluster, and dendrograms were visualized using the Cluster and TreeView software programs (Eisen Lab, Berkeley, CA, USA) (3).

\section{RESULTS}

\section{Physiological Variables and Impedance}

No statistical differences were observed in the physiological data regarding blood gas and electrolyte levels, either before or after cortical vein occlusion. All physiological data were within the normal range (Table II). Impedance data from typical experiments are shown in Figure 2. Cortical impedance was stable under baseline conditions in all of the tested rats.
Within 60-120 s after the $\mathrm{KCl}$ injection into the cortex, a single SD episode was observed for 60-180 s. In some cases, spontaneous SDs occurred, especially in the ischemic group. The total number of both induced and spontaneous SDs was significantly different between the two groups (control group: $0.3 \pm 0.5$; ischemic group: $13.1 \pm 2.7 ; p<0.05$ )

\section{Sequential Changes in Gene Expression after Ischemia and SD}

Changes in gene expression that occurred after 10 episodes of ischemia-induced SD are shown in Figure 3. The c-fos mRNA expression was highly induced at $2 \mathrm{~h}(80.6 \pm 82.1)$,

Table I: RT-PCR Primers Used to Amplify the CDNA of the 13 Studied Genes and the Housekeeping Gene, Glyceraldehyde-3-Phosphate Dehydrogenase (GAPDH). For Each Pair of Primers, 5'-Sense Primers are Placed on the Top and 3'-Antisense Primers are Placed Below

\begin{tabular}{|c|c|c|c|}
\hline \multicolumn{4}{|c|}{ Primers for RT-PCR Amplification } \\
\hline Target Gene & Primer Sequence & Amplicon & $\begin{array}{l}\text { Annealing } \\
\text { temp. }\end{array}$ \\
\hline $\begin{array}{l}\text { glyceraldehyde-3-phosphate } \\
\text { dehydrogenase (GAPDH) }\end{array}$ & $\begin{array}{l}5^{\prime}-\text { CCCACGGCAAGTTCAACGGCA -3' } \\
5^{\prime}-\text { TGGCAGGTTTCTCCAGGCGGC -3' }\end{array}$ & $605 \mathrm{bp}$ & $60^{\circ} \mathrm{C}$ \\
\hline c-fos & 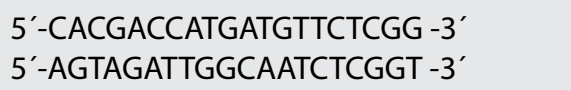 & 566 bp & $60^{\circ} \mathrm{C}$ \\
\hline c-jun & $\begin{array}{l}\text { 5'-GCCTCAGCCGCCGCACCAC -3' } \\
5^{\prime}-\text { CGCCACGTCCTTCCCACTCCA -3' }\end{array}$ & $565 \mathrm{bp}$ & $61^{\circ} \mathrm{C}$ \\
\hline c-myc & $\begin{array}{l}5^{\prime} \text {-AACTTACAATCTGCGAGCCA -3' } \\
5^{\prime} \text {-AGCAGCTCGAATTTCTTCCAGATAT -3' }\end{array}$ & $360 \mathrm{bp}$ & $60^{\circ} \mathrm{C}$ \\
\hline bcl-2 & $\begin{array}{l}\text { 5'-AAGGGGGAAACACCAGAATCAA -3' } \\
\text { 5'- GACCCCACCGAACTCAAAGAA -3' }\end{array}$ & $635 \mathrm{bp}$ & $60^{\circ} \mathrm{C}$ \\
\hline bcl- $x_{L}$ & 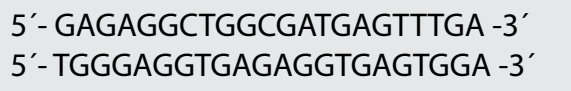 & $466 \mathrm{bp}$ & $60^{\circ} \mathrm{C}$ \\
\hline bax & $\begin{array}{l}5^{\prime}-\text { CCAGGACGCATCCACCAAGAAG -3' } \\
5^{\prime}-\text { GAGGACTCCAGCCACAAAGA -3' }\end{array}$ & 390 bp & $60^{\circ} \mathrm{C}$ \\
\hline bad & $\begin{array}{l}\text { 5'- AGCGGGGACTGAGGAAGAT -3' } \\
5^{\prime} \text { - CGATGGGAGCGGGTAGAAT -3' }\end{array}$ & 311 bp & $60^{\circ} \mathrm{C}$ \\
\hline Cyclin D1 & $\begin{array}{l}\text { 5'-GTGCGTGCAGAGGGAGATTGT-3' } \\
5^{\prime} \text {-CTTCGCGGATGCCACTACTTG-3' }\end{array}$ & $797 \mathrm{bp}$ & $60^{\circ} \mathrm{C}$ \\
\hline p53 & $\begin{array}{l}\text { 5'-GCCATCTACAAGAAGTCACAGC -3' } \\
5^{\prime}-\text { GATGATGGTAAGGATAGGTCGG -3' }\end{array}$ & $284 \mathrm{bp}$ & $60^{\circ} \mathrm{C}$ \\
\hline $\begin{array}{l}\text { heme oxygenase } 1 \\
(\mathrm{HO}-1)\end{array}$ & 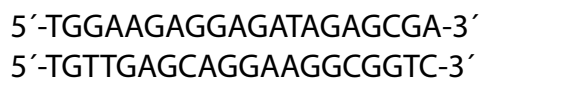 & $449 \mathrm{bp}$ & $60^{\circ} \mathrm{C}$ \\
\hline $\begin{array}{l}\text { cyclooxygenase } 2 \\
(\mathrm{COX}-2)\end{array}$ & $\begin{array}{l}\text { 5'- CATTCTTTGCCCAGCACTTCAC -3' } \\
5^{\prime} \text { - GACCAGGCACCAGACCAAAGAC -3' }\end{array}$ & 296 bp & $59^{\circ} \mathrm{C}$ \\
\hline $\begin{array}{l}\text { superoxide dismutase } 1 \\
\text { (SOD-1) }\end{array}$ & $\begin{array}{l}\text { 5'-GCAGAAGGCAAGCGGTGAA-3' } \\
\text { 5'-CAGTTTAGCAGGACAGCAGATGAG-3 }\end{array}$ & $451 \mathrm{bp}$ & $60^{\circ} \mathrm{C}$ \\
\hline $\begin{array}{l}\text { superoxide dismutase } 1 \\
\text { (SOD-2) }\end{array}$ & $\begin{array}{l}\text { 5'-CCGCCTGCTCTAATCACGAC-3 } \\
5^{\prime} \text {-CCCAGGGCCTCACATAAGACA-3' }\end{array}$ & 756 bp & $60^{\circ} \mathrm{C}$ \\
\hline
\end{tabular}

The top primers of each primer pair are the sense 5' primers and the bottom primers of each pair are the antisense 3' primers. 
Table II: Physiological Parameters Recorded During the Experiment. Values are Expressed as the Means \pm Standard Deviations. MABP, Mean Arterial Blood Pressure

\begin{tabular}{|c|c|c|c|}
\hline & & Control & ischemia \\
\hline & & $n=8$ & $n=17$ \\
\hline Body Weight & & $345.6 \pm 33.9$ & $340.9 \pm 39.2$ \\
\hline \multirow[t]{2}{*}{ MABP: $\mathrm{mmHg}$} & $0 \mathrm{~min}$. & $92.7 \pm 14.2$ & $92.6 \pm 11.3$ \\
\hline & $75 \mathrm{~min}$. & $86.4 \pm 11.2$ & $82.4 \pm 7.5$ \\
\hline \multirow[t]{2}{*}{$\mathrm{PaCO}_{2}: \mathrm{mmHg}$} & $0 \mathrm{~min}$. & $37.5 \pm 3.8$ & $38.4 \pm 3.4$ \\
\hline & $75 \mathrm{~min}$. & $35.8 \pm 2.2$ & $38.4 \pm 2.6$ \\
\hline \multirow[t]{2}{*}{$\mathrm{PaO}_{2}: \mathrm{mmHg}$} & $0 \mathrm{~min}$. & $136.4 \pm 19.4$ & $151.5 \pm 22.3$ \\
\hline & $75 \mathrm{~min}$. & $146.8 \pm 26.3$ & $151.7 \pm 23.3$ \\
\hline \multirow[t]{2}{*}{$\mathrm{pH}$} & $0 \mathrm{~min}$. & $7.45 \pm 0.03$ & $7.42 \pm 0.04$ \\
\hline & $75 \mathrm{~min}$. & $7.41 \pm 0.04$ & $7.37 \pm 0.05$ \\
\hline \multirow[t]{2}{*}{$\mathrm{Hb}: \mathrm{g} / \mathrm{dL}$} & $0 \mathrm{~min}$. & $14.6 \pm 0.7$ & $14.4 \pm 0.9$ \\
\hline & $75 \mathrm{~min}$. & $15.2 \pm 0.4$ & $15.5 \pm 1.2$ \\
\hline \multirow[t]{2}{*}{$\mathrm{Ht}: \%$} & $0 \mathrm{~min}$. & $44.9 \pm 2.2$ & $44.3 \pm 2.6$ \\
\hline & $75 \mathrm{~min}$. & $46.7 \pm 1.2$ & $47.7 \pm 3.7$ \\
\hline \multirow[t]{2}{*}{$\mathrm{Na}: \mathrm{mEq} / \mathrm{L}$} & $0 \mathrm{~min}$. & $1310 \pm 1.6$ & $132.0 \pm 1.5$ \\
\hline & 75 min. & $130.6 \pm 1.5$ & $132.1 \pm 2.4$ \\
\hline \multirow[t]{2}{*}{$\mathrm{K}: \mathrm{mEq} / \mathrm{L}$} & $0 \mathrm{~min}$. & $5.2 \pm 0.2$ & $5.1 \pm 0.4$ \\
\hline & $75 \mathrm{~min}$. & $4.5 \pm 0.2$ & $4.5 \pm 0.6$ \\
\hline
\end{tabular}

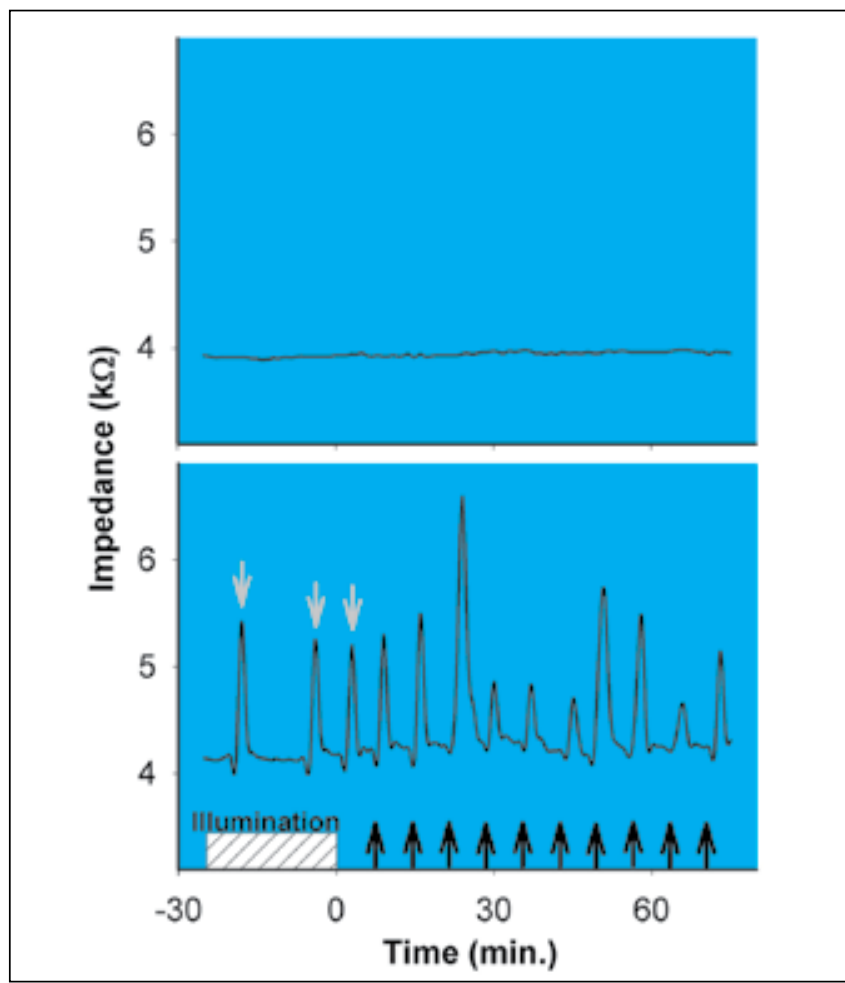

Figure 2: Original recordings from experiments on the control (upper) and ischemic groups (lower). The graphs show sequential changes in impedance of the cerebral tissue. Black arrows indicate the time when the $\mathrm{KCl}$ injections were administered. Gray arrows indicate spontaneous SDs. but rapidly decreased within $8 \mathrm{~h}$ post-ischemia, reaching statistical significance at $24 \mathrm{~h}(1.1 \pm 0.6, p<0.05)$. COX-2 mRNA expression resembled the pattern of c-fos mRNA expression. COX-2 mRNA expression was highly induced within $2 \mathrm{~h}(14.3$ \pm 10.4 ), but rapidly decreased by $8 \mathrm{~h}$, reaching significance at $24 \mathrm{~h}(0.6 \pm 0.2, p<0.05)$

The expression levels of genes in the bcl-2 family were also slightly increased. The bcl-2 mRNA expression was increased at $2 \mathrm{~h}(2.7 \pm 2.7)$, decreased by $8 \mathrm{~h}(0.6 \pm 0.2)$ gradually increasing until $72 \mathrm{~h}(1.3 \pm 0.8)$ post-ischemia. The bcl-xL mRNA expression gradually increased with time, and the expression of this gene at $72 \mathrm{~h}$ post-ischemia $(1.5 \pm 0.3)$ was significantly higher than that measured at $2 \mathrm{~h}$ post-ischemia $(0.9 \pm 0.2, p$ $<0.05$ ). HO-1 mRNA expression at $72 \mathrm{~h}$ post-ischemia was significantly higher than that measured at $24 \mathrm{~h}$ post-ischemia

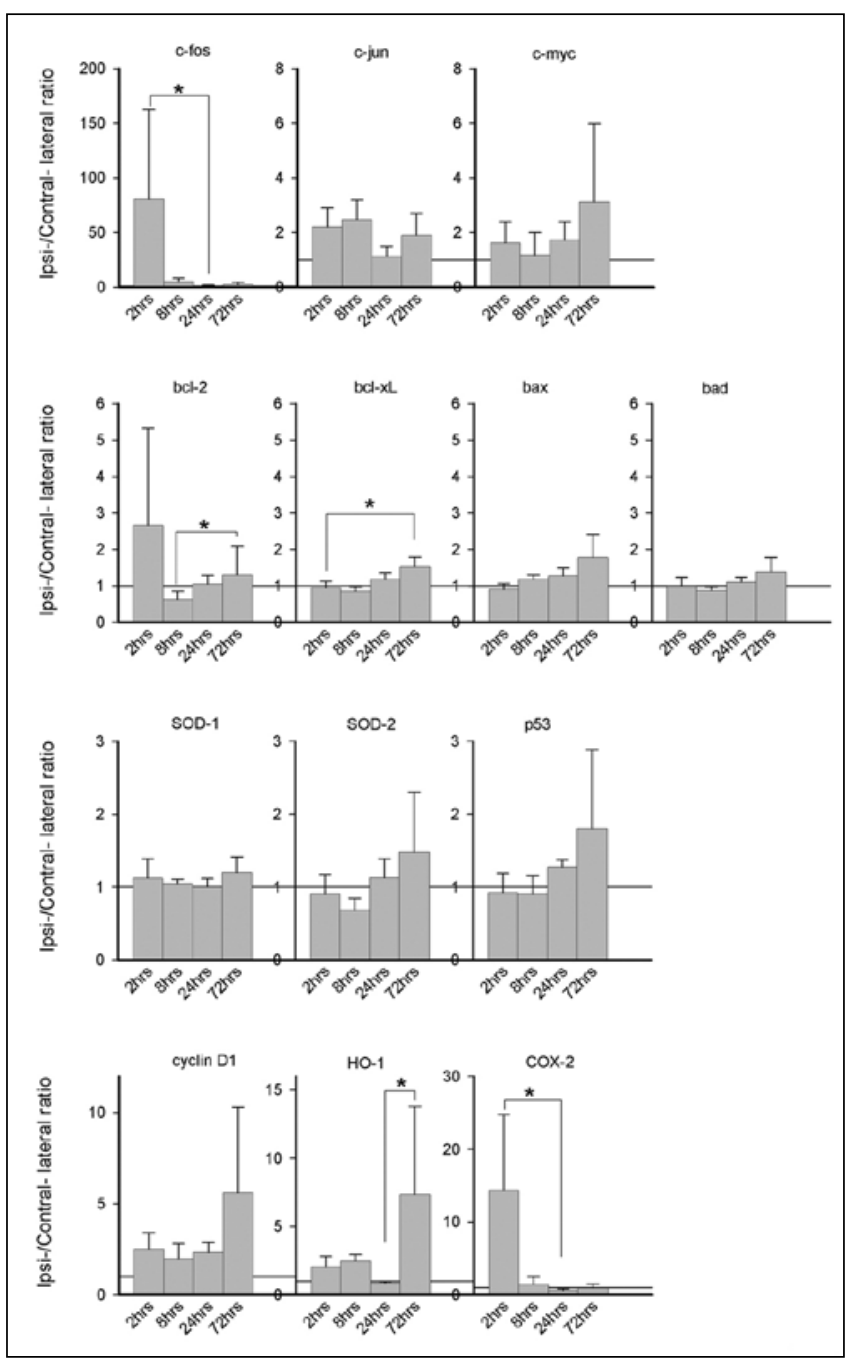

Figure 3: Graphs showing sequential changes in mRNA expression levels of the 13 genes studied in the ischemic group at $2,8,24$, and $72 \mathrm{~h}$ post-ischemia. mRNA expression levels were evaluated as ipsilateral/contralateral ratios by semi-quantitative RT-PCR. The values shown are the means \pm standard deviations. ${ }^{*} p<0.05$ at $2,8,24$, and $72 \mathrm{~h}$ post-surgery for each group; results determined using one-way ANOVA. 
$(7.4 \pm 6.4$ vs. $0.9 \pm 0.1, p<0.05)$. The mRNA expression levels of other genes (e.g., c-jun, c-myc, bax, bad, SOD-1, SOD-2, p53, and cyclin D1) showed no significant differences at 2, 8, 24, and $72 \mathrm{~h}$ post-ischemia in the ischemic group.

\section{Cluster Analysis of Gene Expression Levels after Ischemia and SD}

The dendrogram (Figure 4) of related genes at different time points post-ischemia reveals a close link between early ( 2 and $8 \mathrm{~h}$ ) and late ( 24 and 72 h) changes. Early correlations were observed between COX-2, c-fos, and bcl-2 (group A); c-jun, SOD-1, bad, p53, SOD-2, bcl-xL, and bax (group B); and cyclin D1, c-myc, and HO-1 (group C).

\section{DISCUSSION}

By artificially inducing slowly progressing focal cerebral ischemia, we divided the 13 representative genes into three groups based on the observed sequential patterns in mRNA expression: early, stable, and late expression groups. Different patterns of gene expression would require different therapeutic approaches. For example, if a neurotoxic gene is expressed in the early phase of ischemia, the proper therapy should inhibit mRNA expression, or the protein that is biosynthesized from the mRNA, in order to block ischemic tissue damage. On the contrary, a gene that is expressed in a late phase and protects tissue from ischemic damage might prevent further ischemic damage.

Three genes, c-fos, COX-2, and $\mathrm{HO}-1$, showed significant expression levels at some phase of this experiment. In the early phase, COX-2 and c-fos peaked within $2 \mathrm{~h}$ post-ischemia, while in the late phase $\mathrm{HO}-1$ peaked at $72 \mathrm{~h}$ post-ischemia. These three genes are possible therapeutic targets that could be further developed to treat acute brain ischemia.

First, the inhibition of COX-2 expression following hyperacute brain ischemia could increase following ischemic neuronal damage. The enzyme COX-2 has well-known neurotoxic effects that occur after cerebral ischemia and produce prostaglandins and thromboxanes $(5,10,12)$. Aspirin, a nonspecific inhibitor of COX, prevents the onset of ischemic stroke (14-15). It is commonly believed that the pharmacological action of aspirin to prevent cerebral ischemia is due to its antiplatelet effect (11). The abovementioned experimental studies suggest that aspirin could act via neuroprotective effects. According to our results, after focal cerebral ischemia the expression of COX2 occurs so early that immediate intervention of this gene by administration of antisense in a hyperacute phase would prevent ischemic tissue damage.

In addition, it must be determined if c-fos needs to be controlled while treating acute brain ischemia. This study shows that c-fos mRNA significantly increases during the hyperacute phase after focal cerebral ischemia. Needless to say, c-fos is an immediate early gene (IEG) that is activated immediately after certain kinds of cellular insults, as well as following focal cerebral ischemia $(1,6)$. IEGs play key roles in starting many genetic cascades. Therefore, it is unlikely

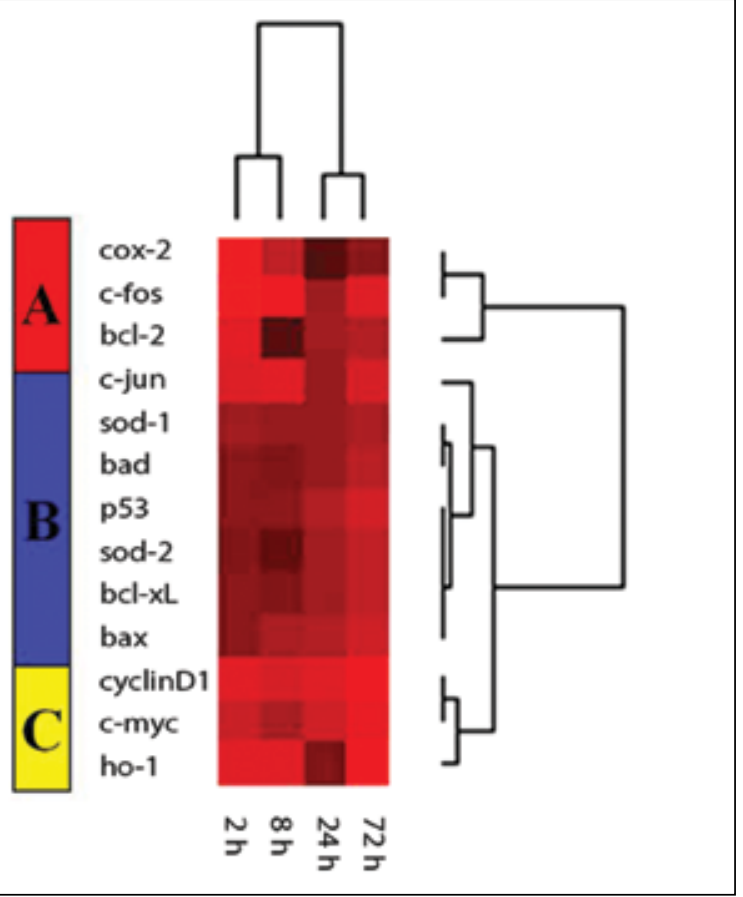

Figure 4: A dendrogram of the results of the cluster analysis showing the relative similarities in expression levels of the 13 studied genes, showing a close linkage between early ( 2 and $8 \mathrm{~h}$ ) and late ( 24 and $72 \mathrm{~h}$ ) changes. Early correlations were observed between COX-2, c-fos, and bcl-2 (group A); c-jun, SOD-1, bad, p53, SOD-2, bcl-xL, and bax (group B); and cyclin D1, c-myc, and HO-1 (group C).

that c-fos has a purely neuroprotective effect, even though a previous study reported that the administration of the antisense oligonucleotide to c-fos mRNA aggravated tissue damage after focal cerebral ischemia (16). For these reasons, the manipulation of c-fos would have its pros and cons.

Third, if the expression of HO-1 mRNA can be pushed forward, ischemic brain damage might be alleviated. HO-1 is a heat shock- or stress-inducible protein. Focal brain ischemia can also induce $\mathrm{HO}-1(4,13)$. Moreover, $\mathrm{HO}-1$ has shown protective effects against cerebral ischemia $(9,13)$. In addition, because the results of this study indicate that there is some delay in the expression of HO-1 following ischemic events, if $\mathrm{HO}-1$ could be coercively expressed in the acute phase of ischemia it could be used in potential treatments against ischemic damage.

To summarize, different genes display different patterns of expression following brain ischemia. By monitoring oligonucleotide microarrays of approximately 30,000 transcripts after global transient ischemia in rat brain, it was determined that the immediate response to transient ischemia is mediated by the induction of specific transcription factors and stress genes (2). Delayed gene expression was characterized by inflammation and a delayed response by immune-related genes. These results suggest that the brain's response to ischemia is an active, specific, and coordinated 
process. The study is in accordance with the results presented here, regarding the fact that different kinds of genes have different patterns of expression.

\section{SUMMARY}

In conclusion, we were able to divide 13 representative genes into three groups based on sequential patterns of mRNA expression: early, stable, and late expression. Three genes, c-fos, COX-2, and HO-1, showed significant expression levels in this experiment. In the early phase, the expression levels of c-fos and COX-2 peaked within $2 \mathrm{~h}$ post-ischemia. In the late phase, $\mathrm{HO}-1$ peaked at $72 \mathrm{~h}$. These results may help to develop a novel genetic treatment for acute cerebral ischemia by widening the time window available for treatment.

\section{ACKNOWLEDGMENTS}

We thank L. Kopacz and M. Malzahn for their excellent technical assistance.

\section{REFERENCES}

1. An G, Lin TN, Liu JS, Xue JJ, He YY, Hsu CY: Expression of c-fos and c-jun family genes after focal cerebral ischemia. Ann Neurol 33: 457-464,1993

2. Buttner F, Cordes C, Gerlach F, Heimann A, Alessandri B, Luxemburger U, Tureci O, Hankeln T, Kempski O, Burmester $\mathrm{T}$ : Genomic response of the rat brain to global ischemia and reperfusion. Brain Res 1252: 1-14, 2009

3. Eisen MB, Spellman PT, Brown PO, Botstein D: Cluster analysis and display of genome-wide expression patterns. Proc Natl Acad Sci U S A 95:14863-14868,1998

4. Geddes JW, Pettigrew LC, Holtz ML, Craddock SD, Maines MD: Permanent focal and transient global cerebral ischemia increase glial and neuronal expression of heme oxygenase-1, but not heme oxygenase-2, protein in rat brain. Neurosci Lett 210: 205-208,1996

5. Kelley KA, Ho L, Winger D, Freire-Moar J, Borelli CB, Aisen PS, Pasinetti GM: Potentiation of excitotoxicity in transgenic mice overexpressing neuronal cyclooxygenase-2. Am J Pathol 155: 995-1004,1999

6. Kinouchi H, Sharp FR, Chan PH, Koistinaho J, Sagar SM, Yoshimoto T: Induction of c-fos, junB, c-jun, and hsp70 mRNA in cortex, thalamus, basal ganglia, and hippocampus following middle cerebral artery occlusion. J Cereb Blood Flow Metab 14: 808-817, 1994
7. Nakagawa I, Alessandri B, Heimann A, Kempski O: MitoKATPchannel opener protects against neuronal death in rat venous ischemia. Neurosurgery 57:334-340; discussion 334-340, 2005

8. Otsuka H, Ueda K, Heimann A, Kempski O: Effects of cortical spreading depression on cortical blood flow, impedance, DC potential, and infarct size in a rat venous infarct model. Exp Neurol 162: 201-214, 2000

9. Panahian N, Yoshiura M, Maines MD: Overexpression of heme oxygenase-1 is neuroprotective in a model of permanent middle cerebral artery occlusion in transgenic mice. J Neurochem 72:1187-1203, 1999

10. Sasaki T, Nakagomi T, Kirino T, Tamura A, Noguchi M, Saito I, Takakura K: Indomethacin ameliorates ischemic neuronal damage in the gerbil hippocampal CA1 sector. Stroke 19: 1399-1403,1988

11. Sato H, Ishikawa K, Kitabatake A, Ogawa S, Maruyama $Y$, Yokota Y, Fukuyama T, Doi Y, Mochizuki S, Izumi T, Takekoshi N, Yoshida K, Hiramori K, Origasa H, Uchiyama S, Matsumoto M, Yamaguchi T, Hori M: Low-dose aspirin for prevention of stroke in low-risk patients with atrial fibrillation: Japan Atrial Fibrillation Stroke Trial. Stroke 37: 447-451, 2006

12. Takeda A, Onodera H, Sugimoto A, Itoyama $Y$, Kogure K, Shibahara S: Increased expression of heme oxygenase mRNA in rat brain following transient forebrain ischemia. Brain Res 666: 120-124,1994

13. Takizawa S, Hirabayashi H, Matsushima K, Tokuoka K, Shinohara $Y$ : Induction of heme oxygenase protein protects neurons in cortex and striatum, but not in hippocampus, against transient forebrain ischemia. J Cereb Blood Flow Metab 18: 559-569, 1998

14. The Dutch TIA Trial Study Group: A comparison of two doses of aspirin ( $30 \mathrm{mg}$ vs. $283 \mathrm{mg}$ a day) in patients after a transient ischemic attack or minor ischemic stroke. The Dutch TIA Trial Study Group. N Engl J Med 325:1261-1266, 1991

15. The SALT Collaborative Group: Swedish Aspirin Low-Dose Trial (SALT) of $75 \mathrm{mg}$ aspirin as secondary prophylaxis after cerebrovascular ischaemic events. The SALT Collaborative Group. Lancet 338: 1345-1349, 1991

16. Zhang Y, Widmayer MA, Zhang B, Cui JK, Baskin DS: Suppression of post-ischemic-induced fos protein expression by an antisense oligonucleotide to c-fos mRNA leads to increased tissue damage. Brain Res 832:112-117, 1999 